\title{
LANGUAGE STIMULATION USING "WAYANG KERTAS" AND STORY BOOKS ON CHILDREN'S SPEAKING SKILLS (4-5 YEARS)
}

Shynta Dinar Audia ${ }^{1 *}$, Faizatur Rohmi ${ }^{1}$, Sekarini ${ }^{1}$

Afiliasi

1. Program Studi Keperawatan Program Sarjana STIKes Kepanjen

Dikirim 7 Februari 2020

Direvisi 22 September 2020

Diterima 28 September 2020

Dipublikasikan 30 November

*Corresponding author

Email :

dinar.audya14@gmail.com

\begin{abstract}
ABSTRAK
Kemampuan berbahasa merupakan salah satu kemampuan dasar yang wajib dimiliki dan dipelajari oleh semua anak usia 4-5 tahun. Media stimulasi pembelajaran bahasa dapat mempengaruhi kemampuan bahasa anak usia prasekolah. Beberapa media pembelajaran yang sesuai adalah media wayang kertas dan buku cerita bergambar. Penelitian ini bertujuan untuk mengetahui perbedaan stimulasi bahasa menggunakan media wayang kertas dan buku cerita bergambar terhadap kemampuan bahasa anak usia prasekolah (4-5 tahun).Desain penelitian ini adalah Eksperimen Design dengan metode One-Shot Case dan Equivalent Control Group dengan jumlah sampel 36 responden. Teknik pengambilan sampel dengan Simple Random Sampling menggunakan uji statistik Uji T Tidak Berpasangan. Pengambilan data dilakukan menggunakan lembar observasi dengan indikator kemampuan bahasa anak usia prasekolah (4-5 tahun).Hasil penelitian menunjukkan bahwa ada perbedaan pengaruh kemampuan bahasa setelah diberikan stimulasi bahasa menggunakan media wayang kertas dan buku cerita bergambar, dengan hasil $p$ value $=0,013$ dan hasil rerata 24,22 untuk kelompok media wayang kerts dan 22,94 untuk kelompok media buku cerita bergambar. Kesimpulan dalam penelitian ini bahwa ada perbedaan pengaruh stimulasi bahasa menggunakan media wayang kertas dan buku cerita bergambar terhadap kemampuan Bahasa. Media wayang kertas dapat memberikan rangsangan pendengaran dan penglihatan sebagai salah satu faktor yang mempengaruhi kemampuan bahasa. Pemberian stimulasi bahasa yang tepat dan secara teratur dapat membuat kemampuan bahasa menjadi lebih optimal.
\end{abstract}

Kata Kunci : Wayang Kertas, Buku Cerita Bergambar, Bahasa, Anak

\begin{abstract}
Language ability is one of the basic abilities that must be possessed and studied by all children aged 4-5 years. Language learning stimulation media can affect the language skills of preschool children. Some suitable learning media are Wayang Kertas (paper puppet) and picture story books. This study aimed to determine the differences between language stimulation using Wayang Kertas media and picture story books on the language skills of preschoolers. This study used Experimental Design with the One-Shot Case and Equivalent Control Group method. The sample were 36 respondents. The sample was obtained using simple random sampling technique and analyzed with independent $T$ test. Data was collected using an observation sheet that the indicators were language skills of preschoolers (4-5 years).The results showed that there was an effect of language skills with the average of Wayang Kertas media groups 24.22 while the picture book media group 22.94 after they were given language stimulation using Wayang Kertas media and picture story books. Statistical test results showed that there were differences between the effect of language stimulation using paper puppet media and picture story books on language skills in preschool children (4-5 years) with a p value $=0.013(0.013<0.05)$.In conclusion, there were differences between the effect of language stimulation using Wayang Kertas media and picture story books on language skills. Wayang Kertas media can give auditory and visual stimulation as one of the factors that influence the language ability. Providing appropriate and regular language stimulation can make language skills more optimal.
\end{abstract}

Keywords: paper puppet, Picture Story Book, Language, Child

Sitasi jurnal :

Audia SD, Rohmi F1, Sekarini. 2020. Language Stimulation Using “Wayang Kertas” And Story Books On Children's Speaking Skills (4-5 Years).Jurnal Ilmu Keperawatan 8(2): 113-123. Doi: 10.21776/ub.jik.2020.008.02.8 


\section{PENDAHULUAN}

Perkembangan bahasa merupakan salah satu perkembangan yang di mulai saat prasekolah yang mana perkembangan bahasa ini wajib dimiliki dan dipelajari oleh setiap anak pada usia prasekolah. Kemampuan berbahasa merupakan indikator seluruh perkembangan anak, karena kemampuan berbahasa sensitif terhadap keterlambatan atau kelainan pada sistem lainnya, seperti kemampuan kogitif, sensorimotor, psikologis, emosi, dan lingkungan disekitar anak. Perkembangan bahasa pada anak mencakup kemampuan untuk mengerti apa yang mereka lihat dan apa yang didengar(Bawono, 2017).

Dari data prevalensi anak usia prasekolah yang keterlambatan berbahasa di Amerika Serikat sebesar $8-12 \%$, dan $10 \%$ anak yang memasuki kelas satu sekolah dasar memiliki hambatan berbicara ringan hingga parah (Buda, 2010). Indonesia mendeteksi adanya gangguan bicara dan bahasa pada anak usia prasekolah mencapai 12\% - 28\% dari 33.265.379 anak pada usia prasekolah (Setyowati, 2010).

Dari hasil tersebut, didapat bahwa masih banyak anak yang mengalami kemampuan berbahasa yang kurang baik. Jika anak mengalami keterlambatan berbahasa akan berakibat buruk, yang menyebabkan keterlambatan dan kerusakan pada sistem kemampuan kognitif, sensori motorik, psikologis, emosi, serta lingkungan disekitar anak (Masganti, 2015). Untuk meningkatkan kemampuan dalam berbahasa anak dapat diberikan media pembelajaran yaitu menggunakan media wayang kertas dan buku cerita.

Media wayang kertas merupakan salah satu contoh media yang cocok untuk bercerita kepada anakanak. Hal tersebut dikarenakan beberapa hal, antara lain warna-warna yang cerah serta bentuk wayang yang lucu dapat menarik minat anak. (Sholichah, 2017). Media wayang dapat memberikan rangsangan pendengaran dan penglihatan sebagai salah satu faktor yang mempengaruhi kemampuan bahasa anak (Daroah, 2013). Sedangkan media buku cerita merupakan cerita yang ditulis dengan gaya bahasa ringan dan mudah di pahami yang dilengkapi dengan gambar yang menjadi satu kesatuan. Keunggulan dari buku cerita bergambar itu sendiri yaitu dapat mengembangkan kemampuan anak dalam aspek bahasa perkembangan bahasa, dan dapat mengasah dalam berbicara anak (Afnida, Fakhriah, \& Fitriani, 2016).
Menurut hasil penelitian yang dilakukan oleh (Astutik, 2016) tentang Penerapan Metode Bercerita Berbantuan Media Wayang Kertas Untuk Meningkatkan Kemampuan Bahasa Anak Kelompok B menunjukkan, dengan diberikannya metode bercerita menggunakan media wayang kertas untuk meningkatkan kemampuan bahasa khususnya kemampuan menyimak menunjukkan peningkatan indikator keberhasilan dari siklus I dibandingkan dengan siklus II diperoleh rata-rata hasil sebesar 65,3\% menjadi $84,65 \%$. Kemudian hasil penelitian yang dilakukan oleh Septiyani tentang Pengaruh Media Big Book Terhadap Kemampuan Berbicara Pada Anak Usia Dini menunjukkan, dengan diberikannya media big book untuk meningkatkan kemampuan berbicara menunjukkan perbedaan yang signifikan antara kemampuan berbicara pada kelompok eksperimen dan kelompok kontrol, dengan hasil analisa data uji statistik nilai t-hitung 5,437 sedangkan t-tabel yaitu 2,145. Dengan kesimpulan hasil hipotesis diterima (Siregar, 2017).

Berdasarkan hasil studi pendahuluan pada tanggal 28 september 2019 di TK Muslimat 10 Kebonsari Ngebruk Kecamatan Sumberpucung Kabupaten Malang menurut keterangan guru dari 10 orang anak, didapatkan 6 orang anak (60\%) belum mengerti perintah yang diberikan, serta 4 orang anak (40\%) belum dapat menjawab pertanyaan yang diberikan. Di TK Muslimat 10 Kebonsari Ngebruk dalam pengajaran perkembangan bahasa biasanya guru menggunakan media buku cerita. Dari pembahasan diatas maka peneliti tertarik untuk melaksanakan dan melakukan penelitian dengan judul "Pengaruh Metode Wayang Kertas Terhadap Perkembangan Bahasa Pada Anak Prasekolah (4-5 Tahun) Di TK Muslimat 10 Kebonsari Ngebruk Kecamatan Sumberpucung Kabupaten Malang.

\section{METODE}

Desain penelitian yang digunakan yaitu desain kelompok kontrol yang sama (Equivalent Control Group Design) merupakan penempatan subyek penelitian dalam dua kelompok yang dibedakan menjadi kategori kelompok eksperimen dan kelompok kontrol. Dari kelompok tersebut, kelompok eksperimen diberi perlakuan dengan media wayang kertas dan 
kelompok kontrol diberikannya media buku cerita bergambar dan desain penelitian One-Shot Case Study dimana penelitian dilaksanakan dengan memberikan intervensi pada suatu kelompok kemudian di observasi pada variabel dependen setelah dilakukan intervensi. Teknik sampling yang digunakan dalam penelititian ini yaitu simple random sampling. Dengan jumlah sampel 36 di TK Muslimat 10 Kebonsari Ngebruk Kecamatan Sumberpucung Kabupaten Malang yang dilaksanakan pada bulan Desember 2019.

Instrumen yang digunakan pada penelitian ini menggunakan lembar observasi. Adapun dalam penelitan ini skala yang digunakan untuk menilai lembar observasi berupa checklist dengan menggunakan skala Guttman. Lembar observasi yang digunakan berisi tentang kemampuan bahasa yang meliputi belajar mengingat-ingat, mengenal huruf dan simbol, mengenal angka, mengenal musim, melengkapi kalimat serta bercerita yang telah diuji validitas dan reliabilitas dengan hasil sig<0,05. (Sulistyawati, 2014)

Penelitian ini dilakukan dengan pemilihan subjek secara acak yang dibagi menjadi 2 kelompok yaitu kelompok media wayang kertas dan buku cerita bergambar, kemudian menjelaskan tujuan penelitian kepada wali responden dan memberikan informed consent selanjutnya dipertemuan pertama peneliti memberikan stimulasi bahasa menggunakan media wayang kertas untuk kelompok eksperimen yang diberikan selama 1 hari, setiap kelompok akan didampingi tenaga enumenator untuk membantu proses pelaksanaan penelitian sekaligus observasi. Pada pertemuan kedua peneliti memberikan stimulasi bahasa menggunakan media buku cerita bergambar untuk kelompok kontrol yang diberikan selama 1 hari, setiap kelompok akan didampingi tenaga enumenator untuk membantu proses pelaksanaan penelitian sekaligus observasi. Data observasi yang terkumpul kemudian ditabulasikan untuk proses analisis data dan interpretasi.

Analisa data yang digunakan pada penelitian ini adalah analisa univariat, yaitu dengan cara mendistribusiakan karakteristik responden meliputi usia dan jenis kelamin. Analisis bivariat menggunakan uji t tidak berpasangan untuk mengetahui perbedaan pengaruh stimulasi bahasa menggunakan media wayang kertas dan buku cerita bergambar terhadap kemampuan bahasa anak usia prasekolah.

Penelitian ini dilaksanakan sesuai dengan prosedur etik dan telah dinyatakan layak etik oleh komisi etik penelitian kesehatan sekolah tinggi ilmu kesehatan kepanjen dengan no. 006/S.Ket/KEPK/ STIKesKPJ/XII/2019.

\section{HASIL}

Berdasarkan penelitian yang dilakukan pada bulan Desember 2019 di TK Muslimat 10 Kebonsari Ngebruk Sumberpucung Malang didapatkan data frekuensi responden total 35 anak. Namun, pada saat dilakukan penelitian terdapat 1 anak yang tidak masuk sekolah. Berdasaran kriteria ekslusi, maka dinyatakan drop out.

\section{Karakteristik Responden}

Tabel 1 : Distribusi Frekuensi Karakteristik Responden Berdasarkan Usia Anak

\begin{tabular}{|c|c|c|c|c|c|}
\hline \multirow[t]{2}{*}{ Variabel } & \multirow[t]{2}{*}{ Kategori } & \multicolumn{2}{|c|}{$\begin{array}{l}\text { Media Wayang Kertas } \\
\qquad(\mathrm{N}=18)\end{array}$} & \multicolumn{2}{|c|}{$\begin{array}{c}\text { Media Buku Cerita } \\
\text { Bergambar } \\
(\mathrm{N}=17)\end{array}$} \\
\hline & & $\mathrm{N}$ & $\%$ & $\mathrm{~N}$ & $\%$ \\
\hline \multirow[t]{3}{*}{ Usia } & 4 tahun & 17 & 94,4 & 16 & 94,1 \\
\hline & 5 tahun & 1 & 5,6 & 1 & 5,6 \\
\hline & Total & 18 & 100 & 17 & 100 \\
\hline \multirow[t]{3}{*}{ Jenis Kelamin } & Laki-laki & 12 & 62,9 & 10 & 58,8 \\
\hline & Perempuan & 6 & 33,3 & 7 & 41,2 \\
\hline & Total & 18 & 100 & 17 & 100 \\
\hline
\end{tabular}

Sumber : Data Primer Penelitian, Deember 2019 
Tabel 1. menunjukkan bahwa sebagian besar responden dari kelompok media wayang kertas dan kelompok buku cerita bergambar berusia 4 tahun yaitu masing-masing 17 anak (94,4\%) dan 16 orang $(94,1 \%)$. Pada kelompok media wayang kertas dan kelompok buku cerita bergambar sebagian besar responden berjenis kelamin laki-laki yaitu 12 anak $(62,9 \%)$ dan 10 anak $(58,8 \%)$

Perbedaan Pengaruh Stimulasi Bahasa Menggunakan Media Wayang Kertas Dan Buku Cerita Bergambar Terhadap Kemampuan Bahasa Anak Usia Prasekolah (4-5 Tahun).

Tabel 3: Deskripsi Perbedaan Kemampuan Bahasa Responden

\begin{tabular}{cccc}
\hline $\begin{array}{c}\text { Stimulasi } \\
\text { Bahasa }\end{array}$ & N & Rerata(s.b) & Nilai p \\
\cline { 1 - 2 } $\begin{array}{c}\text { Wayang } \\
\text { Kertas }\end{array}$ & 18 & $24,22(1,40)$ & \\
& & & 0,013 \\
\cline { 1 - 2 } $\begin{array}{c}\text { Buku Cerita } \\
\text { Bergambar }\end{array}$ & 17 & $22,94(1,49)$ & \\
\hline
\end{tabular}

Sumber : Data Primer Penelitian, Desember 2019)

Berdasarkan tabel 3 diatas didapatkan nilai rerata kelompok media wayang kertas sebesar 24,22 dengan standart deviasi 1,40 sedangkan kelompok media buku cerita bergambar mendapatkan nilai rerata sebesar 22,94 dengan standart deviasi 1,49. Nilai ini menunjukkkan media wayang kertas mendapatkan nilai yang besar dibandingkan media buku cerita bergambar. Berdasarkan analisa data pada penelitian ini menggunakan uji t tidak berpasangan untuk membandingkan kemampuan bahasa antara kelompok buku cerita bergambar dan wayang kertas. Diperoleh nilai $t_{\text {hitung }}$ sebesar 2,638 dengan nilai signifikansi sebesar 0,013 dan nilai $t_{\text {tabel }(5 \% ; 33)}=2,035$. Hal tersebut menunjukkan bahwa ada perbedaan yang signifikan kemampuan bahasa antara kelompok wayang kertas dengan kelompok buku cerita bergambar.

\section{PEMBAHASAN}

Kemampuan Bahasa Anak Usia Prasekolah (4-5tahun) Setelah Diberikan Stimulasi Bahasa Menggunakan Media Wayang Kertas
Berdasarkan analisa deskriptif data usia anak pada kelompok media wayang kertas didapatkan hasil bahwa rata-rata usia responden sebesar 94,4\% yang berada pada usia 4 tahun. Usia responden ini dapat dikataka usia yang baik untuk diberikan stimulasi bahasa. Perkembangan bahasa anak akan berkembang dengan baik jika dari usia dini mereka mendapatkan stimulus oleh lingkungannya. Sesuai dengan (Indah, 2017) yang menyatakan anak-anak cenderung mudah dalam menerima bahasa baru daripada orang dewasa. Proses pemerolehan bahasa memiliki urutan yang sama apabila dimulai sejak usia dini maupun jika diawali pada usia dewasa. Namun di usia ini ada beberapa perbedaannya dari segi kemahiran karena ada hubungannya dengan hipotesis tentang periode kritis pemerolehan bahasa. Usia merupakan salah satu faktor yang masuk kedalam faktor perkembangan bahasa lingkungan postnatal, selain usia faktor perkembangan bahasa lingkungan postnatal lainnya yaitu jenis kelamin pada anak (Mulyawati, 2018)

Pada analisa deskriptif jenis kelamin anak ratarata responden pada kelompok media wayang kertas rata-rata responden berjenis kelamin laki-laki sebesar 62,9\%. Perkembangan bahasa anak perempuan lebih baik dari laki-laki karena perkembangan kognitifnya yang baik, akan tetapi menurut (Wati, 2018) menyatakan pertumbuhan fisik dan motorik pada anak laki-laki dan perempuan berbeda. Anak laki-laki lebih aktif daripada anak perempuan. Hal ini memberi konsekuensi pula pada kondisi kesiapan anak dalam menggunakan bahasanya. Anak yang memiliki kondisi fisik yang sehat tentulah selalu siap. Jika anak selalu dalam kondisi siap, tentulah akan memiliki perhatian yang penuh terhadap rangsangan yang datang termasuk rangsangan dalam berbahasa. Perkembangan bahasa anak akan semakin baik jika orang tua/guru memberikan media pembelajaran yang baru untuk merangsang perkembangan bahasa anak. Salah satu media pembelajaran yang dapat digunakan yaitu media wayang kertas.

Media wayang kertas merupakan media pembelajaran yang baru yang digunakan peneliti yang digunakan untuk menstimulasi perkembangan bahasa anak prasekolah. Wayang kertas merupakan media yang dibuat dengan konsep wayang dengan menggunakan bahan dari kertas. Media wayang kertas merupakan salah satu contoh media pembelajaran 
dua demensi dalam kategori media tradisional yang berbentuk media visual karena bentuknya gambar atau foto sebagai wujud tokoh wayang. Selain itu media wayang kertas termasuk dalam media permainan karena terdapat simulasi atau pemeragaan dalam memainkan wayang kertas. Media wayang kertas merupakan salah satu contoh media yang cocok untuk bercerita kepada anak-anak. Hal tersebut dikarenakan beberapa hal keunggulan media wayang lainnya yaitu dalam proses pembelajaran mampu dengan cepat meningkatkan kecerdasan dan mengubah sikap pasif ke arah aktif (Rizkiyana, 2019).

Skor hasil postest pada kemampuan bahsa menunjukkan skor tertinggi pada item soal 2 (belajar mengingat-ingat) soal 7 (menganal angka) dan soal 11 (melengkapi kalimat). Hasil tersebut didapatkan karena media wayang ketika dimainkan anak dapat melihat tokoh yang dimainkan dan mendengarkan apa yang pemateri berikan sehingga anak dalam hal ini mampu menguasi indikator kemampuan bahasa pada bagian-bagian tersebut, sama seperti (Daroah, 2013) media wayang dapat memberikan rangsangan pendengaran dan penglihatan sebagai salah satu faktor yang mempengaruhi kemampuan bahasa anak. Media wayang sebagai media pengajaran merupakan bahan, alat, dan manusia yang merupakan bagian dari sistem instruksional dan berfungsi sebagai penyalur informasi kepada anak agar anak agar terangsang pikiran, perasaan, dan perhatiannya dalam memperoleh pengetahuan, keterampilan, atau sikap selama proses belajar-mengajar berlangsung (Hendarwati, 2014). Selain itu media wayang kertas merupakan media pembelajaran yang baru diberikan sehingga media tersebut dapat memberikan pengalaman yang bermakna yang belum pernah dilihat sebelumnya dan dapat meningkatkan gairah belajar pada siswa serta memudahkan siswa dalam memahami sesuatu yang abstrak menjadi sesuatu yang kongkrit (Fujiyanto, Jayadinata, \& Kurnia, 2016). Hasil tersebut sesuai dengan (Darmayanti, Tegeh, \& Ujianti, 2017) yang menunjukkan kemampuan bercakap-cakap anak antara kelompok anak yang dibelajarkan metode bercerita dengan media boneka wayang lebih baik daripada kelompok anak yang menggunakan model pembelajaran konvensional.

\section{Kemampuan Bahasa Pada anak usia prasekolah (4-5 tahun) setelah diberikan stimulasi bahasa menggunakan media buku cerita bergambar}

Berdasarkan analisa deskriptif data usia anak pada kelompok buku ceita bergambar didapatkan hasil bahwa rata-rata usia responden sebesar $94,1 \%$ yang berada pada usia 4 tahun. Usia responden ini merupakan usia yang baik untuk anak mendapatkan stimulus bahasa, menurut (Fitriyani, Sumantri, \& Supena, 2018) menyatakan bahwa bayi akan lebih cepat mengalami penambahan kosakata ketika orang tua sering mengulang suara yang keluar dari bayi dan mengajak mereka bicara. Selain faktor usia, jenis kelamin anak juga dapat mempengarui perkembangan bahasa (Septiyani \& Kurniah, 2017)

Pada analisa deskriptif data jenis kelamin anak responden kelompok media buku cerita bergambar sebesar 62,9\% berjenis kelamin laki-laki. Pada perkembangan bahasa jenis kealamin mempengaruhi perkembangan bahasa, karena ketika anak perempuan maupun laki-laki mendapatkan stimulus bahasa yang baik maka mereka sama-sama akan memiliki perkembangan bahasa yang baik. Sesuai dengan (Madyawati, 2018) yang menyatakan bahwa pada tahun pertama usia anak, tidak ada perbedaan dalam vokalisasi antara pria dengan wanita. Namun mulai usia dua tahun anak wanita menunjukkan perkembangan yang lebih cepat dibandingkan dengan anak pria. Namun perkembangan bahasa tergantung pada kemampuan kognitif tertentu, kemampuan pengolahan informasi dan motivasi yang merupakan sifat bawaan. Selain itu juga bahwa bawaan lahir, faktor biologis, menjadi pengaruh alamiah dan bukan bentukan. Perkembangan bahasa anak juga dipengaruhi oleh media pembelajaran yang digunakan oleh guru dikelas. Media pembelajaran yang paring sering digunakan pada tempat penelitan yaitu media buku cerita bergambar.

Buku cerita bergambar merupakan media pembelajaran yang sering digunakan guru sekolah untuk menstimulasi perkembangan bahasa anak. Selain menarik dengan gambar dan ceritanya buku cerita bergambar merupakan media yang tepat untuk menstimulasi perkembangan bahasa anak prasekolah. Stimulasi yang diterapkan media ini yaitu bercerita sehingga dapat menambah kosa kata anak, kemudian 
mendorong anak untuk melihat buku cerita, bertanya, melihat simbol-simbol yang ada pada buku dan dapat mengeksplor cerita. Buku cerita bergambar merupakan buku yang menampilkan gambar dan teks dan keduanya saling berhubungan Dengan demikian, pembacaan terhadap buku cerita bacaan tersebut akan terasa lebih lengkap dan konkret jika dilakukan dengan melihat (Soetjiningsih, 2016).

Skor hasil postest pada kemampuan bahasa menunjukkan skor tertinggi pada item soal 6 (mengenal huruf dan simbol) soal 7 (mengenal angka) dan soal 11 (melengkapi kalimat). Hasil tersebut didapatkan karena media buku cerita bergambar merupakan media yang dapat memberikan rangsangan pendengaran karena dengan mendengar anak akan mendapatkan rangsangan yang baik bagi kemampuan bahasa mereka. Menurut (Zaini \& Dewi, 2017) Media buku cerita bergambar sebagai media pembelajaran menampilkan realitas materi dapat memberikan pengalaman nyata pada anak saat mempelajarinya sehingga mendorong adanya aktivitas diri, pemakaian media pembelajaran dalam proses belajar mengajar dapat membangkitkan keinginan dan minat yang baru, membangkitkan motivasi dan rangsangan kegiatan belajar, dan bahkan membawa pengaruh-pengaruh psikologis terhadap anak. Hasil tersebut sesuai dengan (Siregar, 2017) dengan diberikannya media big book (Buku cerita bergambar besar) untuk meningkatkan kemampuan berbicara menunjukkan perbedaan yang signifikan antara kemampuan berbicara pada kelompok eksperimen dan kelompok kontrol.

\section{Pengaruh Stimulasi Bahasa Menggunakan Media Wayang Kertas Dan Buku Cerita Bergambar Terhadap Kemampuan Bahasa Anak Usia Prasekolah (4-5 Tahun)}

Hasil dalam penelitian ini menunjukkan bahwa media wayang kertas memiliki perbedaan pengaruh stimulasi dengan media buku cerita bergambar terhadap kemampuan bahasa pada anak prasekolah (4-5 tahun). Analisa data dilakukan dengan menggunakan uji statistik $t$ tidak berpasangan dengan taraf signifikansi 0.05 menggunakan komputer. Dari perhitungan $\mathrm{t}$ Tidak Berpasangan (Independent Sample $t$ Test), hasil uji statistik diperoleh dengan menggunakan nilai $t_{\text {hitung }}$ dan nilai signifikansi ( $p$ value) yang lebih kecil dari alpha 0,05 . Hal ini sesuai dengan hasil analisa kemampuan bahasa anak setelah dilakukan intervensi bahwa pada kelompok media wayang kertas, diperoleh rata-rata kemampuan bahasa sebesar 24,22 dengan standart deviasi sebesar 1,40. Sedangkan pada kelompok media buku cerita bergambar, diperoleh rata-rata kemampuan bahasa sebesar 22,94 dengan standart deviasi sebesar 1,49.

Hal ini sejalan dengan hasil penelitian penelitian yang dilakukan oleh Astutik (2016) tentang Penerapan metode bercerita berbantuan media wayang kertas untuk meningkatkan kemampuan bahasa anak kelompok B menunjukkan, dengan diberikkannya metode bercerita menggunakan media wayang kertas untuk meningkatkan kemampuan bahasa khususnya kemampuan menyimak menunjukkan peningkatan indikator keberhasilan dari siklus I dibandingkan dengan siklus II diperoleh rata-rata hasil sebesar $65,3 \%$ menjadi $84,65 \%$.

Metode stimulasi bahasa menggunakan media wayang kertas dilakukan pada pukul 08.00 pagi pemberian stimulasi ini berlangsung selama 20 menit, pemberian stimulasi ini tidak terlalu lama sehingga anak tidak mengalami kebosanan dan pemberian dilakukan pada pagi hari karena pada pagi hari pikiran anak masih fresh. Selain hal tersebut beberapa hal lainnya karena keunggulan media wayang lainnya yaitu dalam proses pembelajaran mampu dengan cepat meningkatkan kecerdasan dan mengubah sikap pasif ke arah aktif, media wayang dapat memberikan rangsangan pendengaran dan penglihatan sebagai salah satu faktor yang mempengaruhi kemampuan bahasa anak (Daroah, 2013).

Faktor-faktor yang memengaruhi perkembangan bahasa pada anak usia 4-5 tahun, diantaranya yaitu faktor kesehatan, intelegensi, status sosial ekonomi keluarga, jenis kelamin, usia, hubungan keluarga, serta pendidikan orang tua. Namun faktor lingkungan/sosial dimana seorang anakitu berada menjadi salah satu faktor penentu dalam penciptaan lingkungan bahasa yang baik (Yusuf, 2007). Faktor lingkungan ini juga didapatkan dari orang tua anak dan pekerjaan orang tua. Rata-rata pekerjaan orangtua responden yaitu bekerja swasta, orangtua yang bekerja swasta ini memiliki banyak waktu untuk anak dengan begitu orangtua akan membantu anak dalam hal belajar serta memantau apa saja perkembangan anak termasuk perkembangan bahasa anak. Dalam pekerjaan ini orang tua juga mampu menfasilitasi anak dengan media pembelajaran untuk anak mereka. Tempat utama 
yang digunakan untuk memfasilitasi perkembangan bahasa pada anak yaitu keluarga, di keluarga inilah lingkungan terdekat anak. Sejak bayi samapai usia 6 bulan, anak lebih banyak menghabiskan waktunya untuk berada di rumah sehingga intensitas berinteraksi dengan anggota keluarga lebih banyak. Anak dan orang tua akan

\section{KESIMPULAN}

Dari hasil penelitian dan pembahasan yang dilakukan dapat disimpulkan bahwa ada perbedaan pengaruh stimulasi bahasa pada kelompok media wayang kertas dan buku cerita bergambar terhadap kemampuan bahasa anak usia prasekolah. Diharapkan

\section{DAFTAR PUSTAKA}

Afnida, M., Fakhriah, \& Fitriani, D. (2016). Penggunaan Buku Cerita Bergambar Dalam Pengembangan Bahasa Anak Pada Tk a Di Banda Aceh. Jurnal Ilmiah Mahasiswa Pendidikan Anak Usia Dini, 1(1), 52-59. Retrieved from https://media. neliti.com/media/publications/187164-IDnone.pdf

Astutik, A. D. T. (2016). Efektifitas Media Wayang Kertas Dalam Pembeljaran Ketrampilan Berbicara Bahasa Prancis Kelas X SMA Negeri 9 Yogyakarta.

Bawono, Y. (2017). Kemampuan berbahasa pada anak prasekolah: Sebuah kajian pustaka. Prosiding Temu Ilmiah X Ikatan Psikologi Perkembangan Indonesia, 116-125.

Buda, E. S. (2010). Hubungan Antara Pengetahuan, Sikap dan Perilaku Ibu Dengan Perkembangan Bahasa Anak Usia 24-36 Bulan Study di Kelurahan Krembangan Selatan Kecamatan Krembangan Surabaya.

Darmayanti, P., Tegeh, I. M., \& Ujianti, R. (2017). Terhadap Kemampuan Bercakap-Cakap Anak Kelompok B Di Tk Widya Sesana Sangsit 2016/2017. E-Journal Pendidikan Anak Usia Dini Universitas Pendidikan Ganesha Jurusan Pendidikan Guru Pendidikan Anak Usia Dini (Volume, 5(1), 336-347.

Daroah. (2013). Menumgkatkan Kemampuan Bahasa Melalui Metode Bercerita Dengan Media Audio Visual Di Kelompok B1 RA Perwanida 02 Slawi. In Jurnal Teknologi (Vol. 1). https://doi. org/10.11113/jt.v56.60 terlibat aktif dalam berbicara (Sumaryanti, 2017). Orang tua yang mempunyai pekerjaan dan pendapatan yang mencukupi akan mendukung proses tumbuh kembang anak karena orang tua mampu memberikan fasilitas untuk memenuhi semua kebutuhan dasar anak (Safitri, 2017).

pada penelitian selanjutnya dapat melanjutkan penelitian ini dengan mengganti tokoh wayang kertas yang ada dalam cerita maupun mengganti ceritanya yang dapat membuat anak menguasai semua indikator kemampuan bahasa usia prasekolah

Fitriyani, Sumantri, M. S., \& Supena, A. (2018). Gambaran Perkembangan Berbahasa pada Anak dengan Keterlambatan Bicara (Speech Delay): Study Kasus pada Anak Usia 9 Tahun Kelas 3 SD di SDS Bangun Mandiri. Prosiding Seminar Dan Diskusi Nasional Pendidikan Dasar 2018, 59-64.

Fujiyanto, A., Jayadinata, A. K., \& Kurnia, D. (2016). Penggunaan Media Audio Visual Untuk Meningkatkan Hasil Belajar Siswa Pada Materi Hubungan Antarmakhluk Hidup. Jurnal Pena Ilmiah, 1(1), 841-850. https://doi. org/10.23819/pi.v1i1.3576

Hendarwati, E. (2014). Pemanfaatan Media Dalam Pembelajaran Pengetahuan Sosial Di Taman Kanak-Kanak. Jurnal Pedagogi, 1 (Media, Pengetahuan Sosial, Taman Kanak-kanak ABSTRACT), 1-30.

Indah, R. N. (2017). Gangguan berbahasa: Kajian pengantar. Retrieved from http://repository. uin-malang.ac.id/1296/6/1296.pdf

Madyawati, L. (2018). Strategi Pengembangan Bahasa.

Masganti. (2015). Psikologi perkembangan anak usia dini.

Mulyawati, A. R. (2018). Meningkatkan Kemampuan Berbahasa Melalui Metode Bercerita Dengan Gambar Seri Pada Kelompok B. 1-13.

Rizkiyana, M. (2019). Meningkatkan Perkembangan Bahasa Anak Usia Dini Melalui Media Bergambar Kelompok A Di TK Aisyiah Bustanul Athfal Wates Gadingrejo Pringsewu. 
Safitri, Y. (2017). Faktor-Faktor yang Berhubungan dengan Perkembangan Bahasa Balita di UPTD Kesehatan Baserah Tahun 2016. 1(2), 148-155. https://doi.org/10.31004/obsesi.v1i2.35

Septiyani, S., \& Kurniah, N. (2017). Pengaruh Media Gig Book Terhadap Kemampuan Berbicara Pada Anak Usia Dini. Jurnal Potensia, 2, 47-56.

Sholichah, M. (2017). Efektivitas Penggunaan Media Wayang Koran Dalam Pembelajaran Keterampilan Bercerita Anak Kelompok B. PAUD Teratai, 6(2).

Siregar, R. F. (2017). Penerapan Media BUku Cerita Bergambar (Big Book) Dalam Perkembangan Bahasa Anak Usia Dini Kelompok B Di RA Nurul Iman Kecamatan Pantai Cermin Kabupaten Serdan Bedagai. (September), 1-215.
Soetjiningsih, dan I. N. G. R. (2016). Tumbuh Kembang Anak Edisi 2 (2nd ed.). Jakarta: EGC.

Sumaryanti, L. (2017). Peran Lingkungan Terhadap Perkembangan Bahasa Anak. 01(01), 1-18. Retrieved from http://www.albayan.ae

Wati, N. S. (2018). Pengaruh Stimulasi Mendengarkan Lagu Dan Bernyayi Terhadap Perkembangan Berbahasa Pada Anak Usia Dini. Elementary: Jurnal Ilmiah Pendidikan Dasar, 4(1), 75. https:// doi.org/10.32332/elementary.v4i1.1081

Yusuf, S. (2007). Psikologi Perkembangan Anak dan Remaja. Bandung: PT Remaja Rosdakarya Offset.

Zaini, H., \& Dewi, K. (2017). Pentingnya Media Pembelajaran Untuk Anak Usia Dini. Raudhatul Athfal:Jurnal Pendidikan Islam Anak Usia Dini, 1(1), 81-96. https://doi.org/10.19109/ra.v1i1.1489 